\title{
ALL-SOCIETY ECONOMIC BENEFITS THROUGH USAGE OF BROWNFIELD
}

\author{
Matej Bunat*1 \\ ${ }^{1}$ CTU in Prague, Thakurova 2077/7, Prague 6, 160 00, Czech Republic, matej.bunat@fsv.cvut.cz
}

\begin{abstract}
The investor, the designer, and the Building authority are subjects who decide about placing new buildings. There are two possibilities of placing: either on a greenfield or on so-called brownfield.

Terms like sustainable development, spatial planning, brownfield, and greenfield are related to this topic. The possibilities of revitalization of brownfields are also discussed. For an objective judgment of possible usage of the brownfield for the investor, it is necessary to use all the possible methods of decision especially model $3 \mathrm{E}$. To choose a locality and to think through all the positive as well as negative impacts of planned building on a brownfield, it is useful to create a mind map as scheme of possible impacts and to define criteria for all the major subjects involved in the building construction.
\end{abstract}

\section{Keywords}

Brownfield, sustainable development, revitalization, economic effectiveness, positive and negative impacts.

\section{JEL Classification}

Q01, 018, 021.

DOI: https://doi.org/10.14311/bit.2018.01.05

Editorial information: journal Business \& IT, ISSN 2570-7434, CreativeCommons license (c) (i) published by CTU in Prague, 2018, http://bit.fsv.cvut.cz/ 


\section{Introduction}

Czech construction industry is slowly recovering from the last seven years of economic crisis (20072015). As the result of this process, demand for construction works and building new objects (blocks of flats, offices, etc.) is increasing. It is very important to choose a convenient location for each new object.

The answer for the fundamental question "where to build" is not simple. Usually, there are only two possibilities: either on a greenfield or on so-called brownfield.

The big advantage of choosing brownfield and unused places of the same character consist in its easy accessibility to the network.

Brownfields and their possible revitalization is convenient in most cases not only for the investor. It usually brings an all-society effect. Former industrial areas, which are now being used as cultural or community centres, can be used as an example of this matter. With using so called $3 \mathrm{E}$ evaluation, it is possible to professionally show the differences between the choices for the building. One of the main reasons to be concerned about the matter of brownfield is sustainable development and the environment.

\section{Spatial planning and sustainable development}

Spatial planning is and interdisciplinary activity, which offers the possibility of equal cooperation of engineers (in the fields of geodetic work, construction, traffic planning, water industry planning etc.) with architects, biologists, ecologists. None of them is superior to another, it should be a perfect cooperation of all subjects [1]. Every municipality holds its own spatial plan and defines its basic framework for using the spaces, which can be divided into urbanized and un-urbanized [2].

Urbanism as a science started at the edge of 20th century [3]. Urbanism realises the process of urbanisation (becoming urban), which uses the process of becoming urban, in other words it tries to concentrate the economic and the cultural into the town and cities rather into the smaller villages and thus enlarging the urbanized spaces of the cities. Urbanisation is also supported by the fact, that the inhabitants are centred in the cities. [4]

Spatial plans of all extends should correspond with the idea of sustainable development. The theory of sustainable development tries to rebuild man's relationship with nature. The task of this theory is to sustain the quality of the current and future generation's lives in terms of time and space. The horizon of time formulates aims of responsibility and solidarity between the generations while the spatial horizon sets these aims for the communities, which share Earth as their homes (continents, regions, states etc.). [5]

The theory of sustainable development basically searches for the ideal ways of human living on Earth. For applying the development, it is necessary to look at this problem for the points of view: economic, ecologic and social.

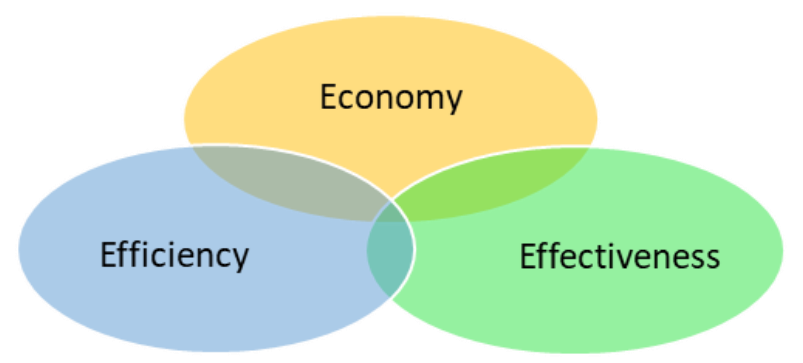

Fig. 1: Three basic pillars of sustainable development [3], processed by the author. 


\section{Brownfield}

In spatial plans, there are two basic possibilities of construction. One of them is to increase the amount of urbanized space, the other one is to try to use the space of so called brownfields. There are many causes of emergence of these and all of them are closely connected to socio-economic changes of the society. The matter of brownfields is not only a current issue, due to their growth it is becoming an issue of the future as well. That is why we need to deal with it. (Fig. 2.) [6]

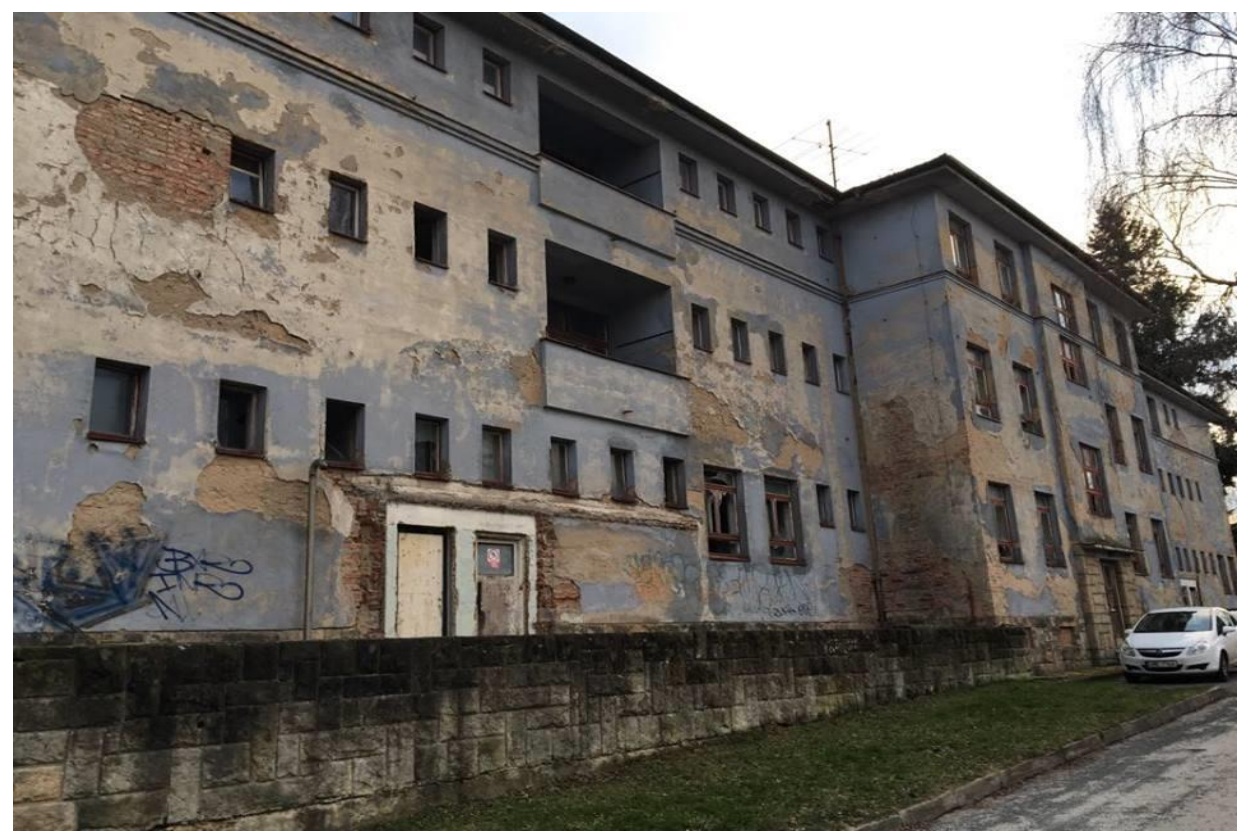

Fig. 2: Brownfield in Kostelec nad Černými lesy: Sanatorium. (source: author)

\section{Defining brownfield}

It is a current issue that there is no definition of brownfield, not only in the Czech Republic, but also abroad, as it is said in the foreign scholarly literature $[7,8]$. One of the reasons why there is lack of broader consensus concerning the definition is that every field adjusts the matter according to its needs and there has not been the need to unify it. Nonetheless all the definitions describe the same problem. As an example, the definition of the Ministry of industry and trade (MPO) in the Czech Republic is cited.

According to MPO [9] the definition is following: Brownfields is a real estate (land, object or campus), which is not being sufficiently used, which is neglected and can be contaminated. It is remnant of industrial, agricultural, residential, military or other activity. Brownfield cannot be conveniently and effectively used unless regeneration has been made.

Foreign definitions are very different from this one and they often lack complex description of the problem.

Denmark: Land affected by contamination. [10]

Ireland: Derelict land: Land which detracts, or is likely to detract, to a material degree from the amenity, character or appearance of land in the neighbourhood of the land in question because of ruinous structures, neglected condition or presence of waste. [10]

England: Previously developed land - land which is or was occupied by a permanent structure (excluding agricultural or forestry buildings), and associated fixed surface infrastructure. [10] 


\section{Revitalization}

There are countless possibilities of restoration of so-called brownfields (Fig. 3). The most used are recovery, revitalization, regeneration and reconstruction.

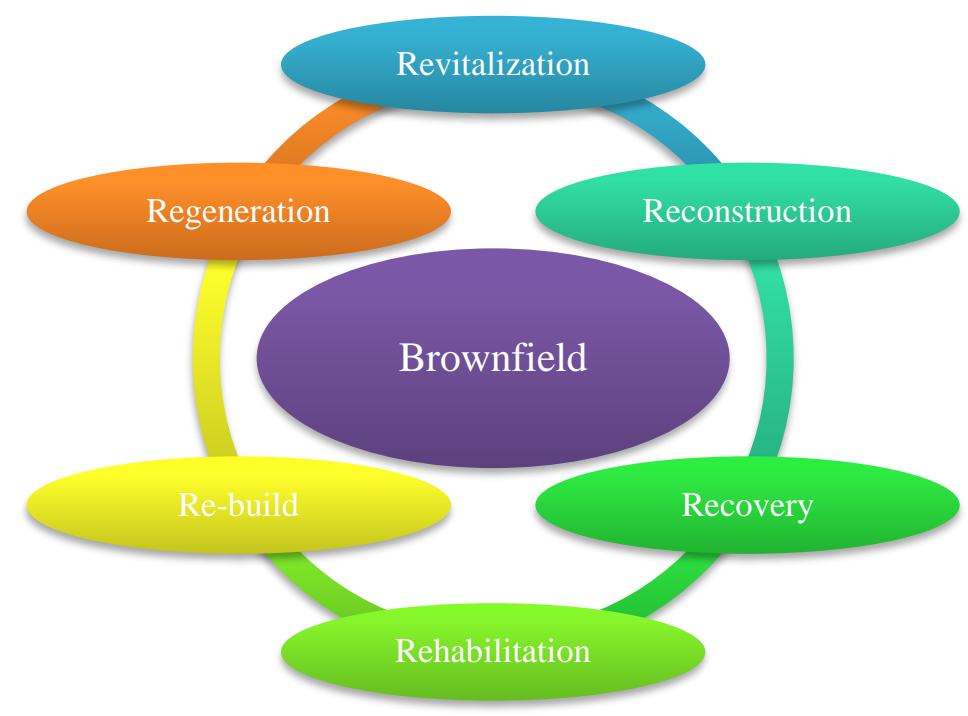

Fig. 3: Brownfield revitalization [11], processed by the author.

\section{Recovery}

Recovery is the oldest term related to management of spatial plans and their urbanization. In the past in most cases it was recovery after wars or natural disasters, those were such places as fatally destroyed spatial wholes or towns. The process of recovery consists of re-covering the space where the life has died out or its basic functions such as the potential for living, civic amenities) have been ruined. There is an advantage of such condition in the possibility to re-plan the former spatial plans and make new ones, on the other hand it is also the most expensive part of the process of revitalization. [12]

\section{Revitalization}

The term revitalization begins to be used in all shapes and cases, especially in the Czech context. It is very often used in the context of brownfields and enhancing the quality of the environment. [13]

The main aim of revitalization is increasing its ecological stability [14], restoration of the country with disrupted rock environment to a pre-human state [15], functional implanting to the country so that something dis-functional becomes functional [16].

In the current economic theory there is an effort to satisfy only the economic needs, there is none to search for a compromise between the economic, ecologic and social dimension so that a convenient restoration of unused spaces (brownfields) is achieved.

\section{Regeneration}

This term is very often used as a synonym of the term revitalization. The meaning of it is slightly different though. It is used when talking about a city, where there is the need to maintain historical, cultural and aesthetical connection. The result of regeneration can be imagined as a functional city lacking unused or needless spaces. It is a systematic process of recovering and maintaining the city. [17]

\section{Reconstruction}

The process of reconstruction is the easiest way of spatial recovering. The initial phase of this process is demolition of needless or ruined buildings and then replacing them with new objects. [18] 


\section{Economic aspects of construction}

In general, every project can be evaluated from several points of view. A specific field of evaluation is following the rules, which are usually related to as $3 \mathrm{E}$. 3E stands for economy, efficiency and effectiveness (Fig. 4).

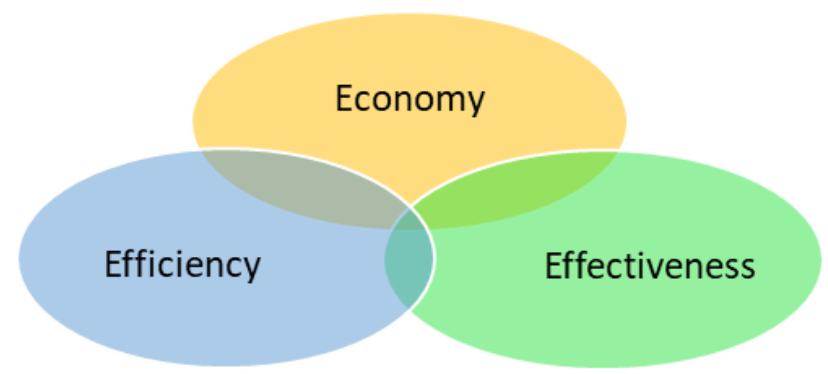

Fig. 4: Model 3E [19], processed by the author.

The 3E method considers minimalizing of expenses important when evaluating a construction as well as the economy of the building, it also seeks for using such means, so they are on optimal degree of gaining the aims. The efficiency along with using the means for best possible outputs is also taken into the process of evaluations. [19]

The economy of the new constructions, especially during the decision-making process considering greenfield on brownfield, has to be viewed from two perspectives. One of them is the perspective of those who realize the project - investor or an engineer. The other perspective is the one of the city and the engineers who provide the municipal engineering. The towns or the municipalities are at the same time responsible for managing the spatial plans on all levels so that they can be effectively and strategically developed.

The idea to develop cities is also supported by the fact that the inhabitants try to move more to the cities and the cities try to stand up to the demand by constructing sustainable buildings for living. But this behaviour if realised at all costs can lead to ineffective management of the cities and lead to even higher costs. One of the reasons of increasing the costs is construction of new engineering networks to the new buildings on greenfield and the costs also grow by the following usage of it. This idea is shown on the scheme (Fig. 5). On the other hand, the investors when making their decisions try to reach the lowest costs possible as well as the shortest time of construction and thus the construction on greenfield becomes the most convenient for them. Nonetheless it is not always the case as it has been proved in the literature [5]. 


\begin{tabular}{|llll|}
\hline View of the city & Brownfield & $<$ & Greenfield \\
View of the investor & Brownfield & $>=$ & Greenfield \\
\hline
\end{tabular}

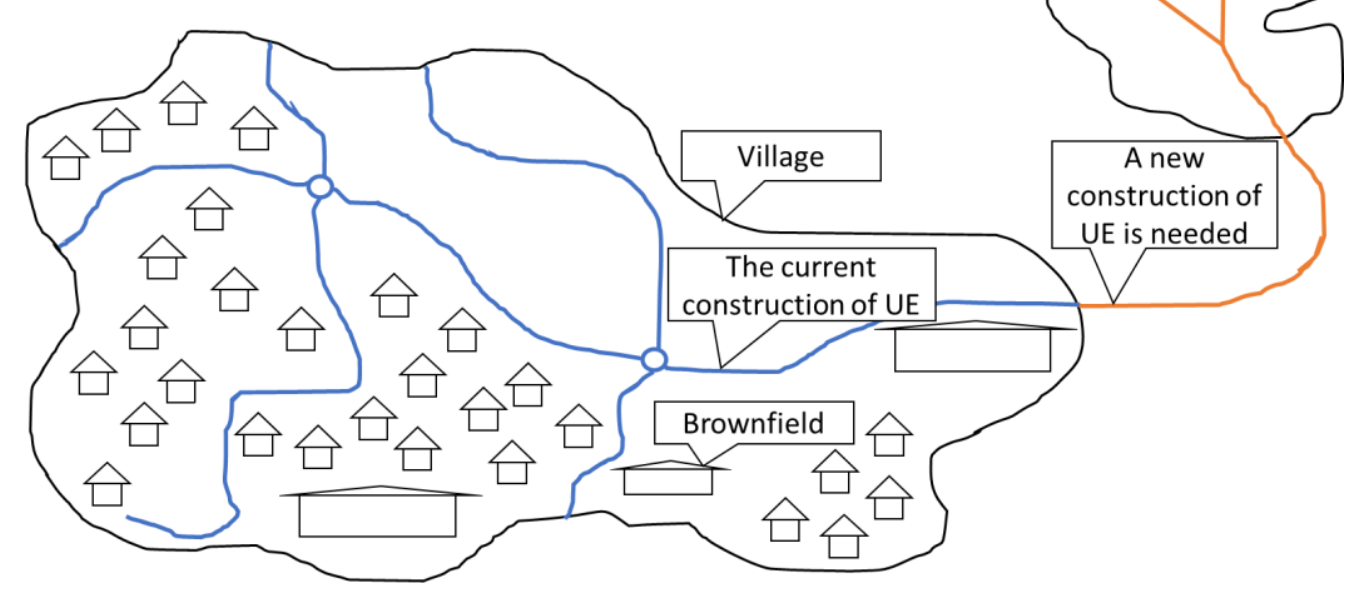

Fig. 5: General scheme of financial burden for the village during construction on greenfield. [5]

\section{Economic aspects}

One of the key aspects concerning construction is the economic claim of the construction, which is closely connected to the economy. The financial flow does not end with the revitalization (construction or reconstruction of an object), an important role also has the preparation for it and the following usage of it and an ecologic demolition as it is shown in the life cycle of a construction (Life Cycle Cost) according to [20]. The cycle shows all the expands during the whole time of the lifetime of the construction - the acquisition costs and the investing part of the project, the costs of the realisation, the costs for the usage, its maintenance and recovery and finally the ecologic demolition of it [21].

$$
L C C=I+r+R_{e}-R_{s}+D+E+W+M+O
$$

$\begin{array}{lll}L C C & = & \text { Total Life-Cycle Cost (present value), } \\ \text { where } & = & \text { Initial investment cost of the structure, } \\ r & = & \text { Interest paid on the loan amount used to purchase the building } \\ R_{e} & =\quad \text { Replacement cost of the building } \\ R_{s} & =\quad \text { Desale or salvage value of the structure at the end of this useful life } \\ D & =\quad \text { Estimated energy costs of the structure } \\ E & =\quad \text { Estimated water costs of the structure, } \\ W & =\quad \text { Estimated maintenance, repair, and upkeep costs of the structure } \\ M & =\quad \text { Estimated other costs associated with ownership of the structure }\end{array}$

The Life Cycle of a building is used as an evaluation tool for comparing individual types of buildings, used technologies, the size of the project etc. It is necessary to consider LCC approach because of the whole effectiveness of the building as well as look at all the levels of vitality of the building. For example, the qualities of wood including its renewability show wood as a convenient material due to its low financial and energetic costs. 
There is a tool for financial numbering of the economic costs of revitalization called "expands reserves" which represents a direct element of positive discrimination. When using it a calculation using formula (2) due to [22] can be applied. This formula is set based on an expert opinion. The meaning of such calculation is assessing the trading value of the property before and after its valorisation. The differential between these two numbers, lowered by the expenses connected with this activity, creates the expand reserve.

$$
C G=C_{1}+C_{2}+C_{3}-S
$$

$\begin{array}{lll}\text { where } \quad C G & = & \begin{array}{l}\text { Cost gap } \\ C_{1}\end{array} \\ C_{2} & = & \text { Cost of the acquisition of real estate, } \\ C_{3} & = & \text { Cost of technical preparation of the project, } \\ S & = & \text { Sale price of real estate. }\end{array}$

\section{Economic aspects of construction}

It is necessary to have in mind that the potential revitalization is related to draining the unused environment for every item. Because of that it is convenient to create a potential drain for each perspective separately (ecology, economy, social perspective etc.) and assign certain importance to it. That should be done in such a way, so that multi-criterion decision making process can be realised and an objective selection can be done. Each project of revitalization can be seen, as a business plan. It is necessary to try to use the space as effectively as possible.

Having stated that it brings the discussion to a well-known fact that every construction project is special and unique and thus the evaluation of it has to be made for every project individually. It is also necessary, as it has been stated before, to create the decision-making processes for all the involved subjects (for the investor, the designer, the state, the municipality, the inhabitants etc.) and in all possible scenarios.

Another fact is that, there is more brownfields than the demand asks for which causes decrease of its prices, and not only of the prices of the brownfields but also of the lands surrounding them. The reason why investors choose to build of greenfield rather than on brownfields is lower costs as proved by the statistics of Čsú (Czech Statistical Office). But when the orientation cost in the pre-investing stage are compared, it can be shown that it does not correlate in $100 \%$.

To show this disproportion it can be pointed to the fact that it is not the most convenient solution to use only the perspective of economic effectiveness. There is an aim to keep the production potential of the country, to minimalize future economic granting. It is convenient to think about project as a complex whole, which will be evaluated in different fields of studies and to create individual complex solutions, which has to be viable and acceptable for the public. Finally, it is most convenient to create a project, which will not be likely to turn into brownfield.

Another important problem is the owning of the brownfields lands of objects. Most of them are owned by the state, some of them are held as private property. In most cases they are owned by companies, very rarely by natural person. There are also spaces where there are several owners of them. It is not possible to identify the procedural share of owning because there is no complete list of brownfields. The available information (Czechlnvest, ČÚZK, ČSÚ) was used to create a chart (Fig. 6), which shows that most of the brownfields is owned by the state and so it is in the interest of the state to revitalize them. 


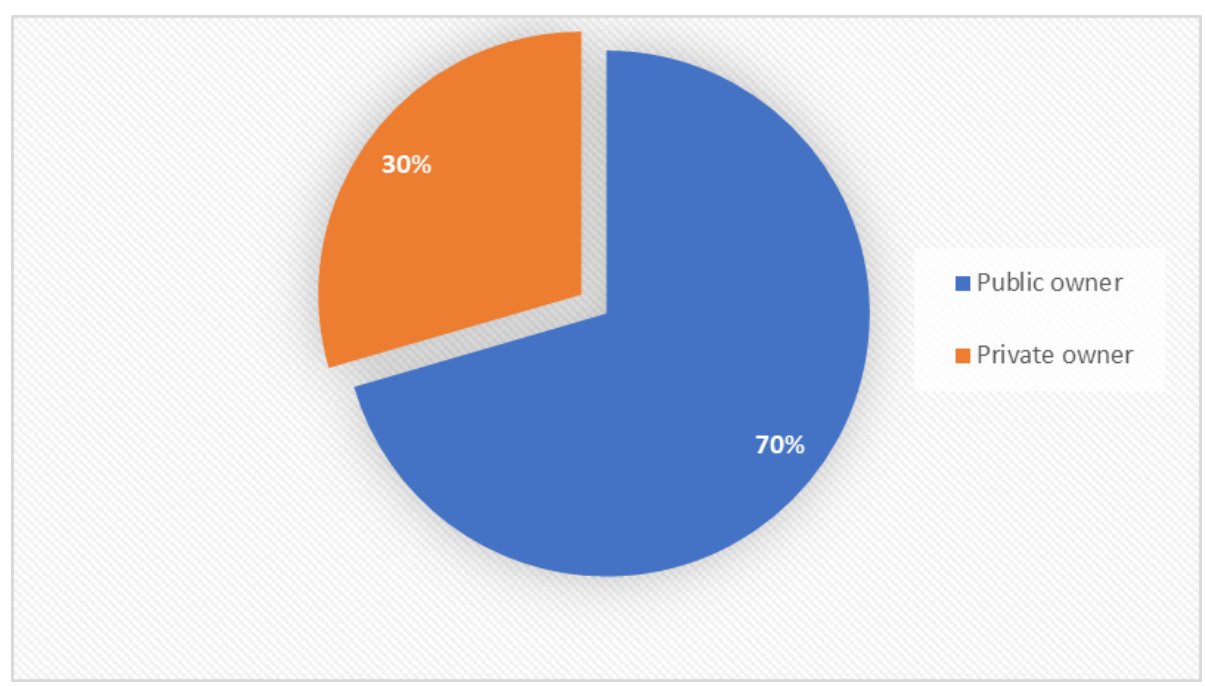

Fig. 6: Share of brownfield sites in the Czech Republic by type of ownership (Czechlnvest, ČÚZK, Čsú).

In the Czech Republic the current issue regarding brownfields is empathizing its relation to economy. The investors keep focusing only on the economic aspects of revitalization of brownfields, analyzing indexes of GDP, unemployment etc. in relation to brownfields in a specific area [23]. They also categorize brownfields and count out the economic severity of the revitalization. The existence of brownfields contributes to growth of cities (growth of urbanized space in cities) and thus the expenses of usage grow as well. There is no effort though, that would focus on effective creation of brownfields database, which would lead to easier process of its revitalization.

The situation abroad is very similar. There is little interest in the scholarly literature in connecting the topic of brownfields with economy. American authors [7] for example have troubles with defining brownfield, they base their definition on the degree of contamination of the areas and focus on counting the growing costs connected with revitalization of such areas, these costs grow as there is high pollution of the rock base. There authors [8] then search for solutions of the situation. In other articles it is concluded that using greenfield is the more effective choice of construction, because of the time needed for transport of the material through the city and also because of possible reduction of greenhouse gases and pollution [24]. There is also no effective brownfield database. The benefit of such database is undoubted.

The following figures (Fig. 7 and Fig. 8) deal with a comparison of the findings which show negative and positive impacts of construction on greenfield and brownfields from the point of view of the main subject involved investor (designer), municipality (state), inhabitants (the public).

Positive and negative impacts divide all the results of the construction into pros and cons of it. Every construction brings many pros such as the possibility to use new space, building of new infrastructure on places where it has been missed, creating a new meeting point for people, creating a new cultural centre, new fitness centre, new apartment house. It is often accompanied by new impulses for the people, new opportunities and new possibilities for satisfying their needs and desires. In some cases, the scheme cannot be utterly right, because every project is different and original and so there cannot be one universal true model made. With every positive effect there is a negative one arising for a different subject involved. 

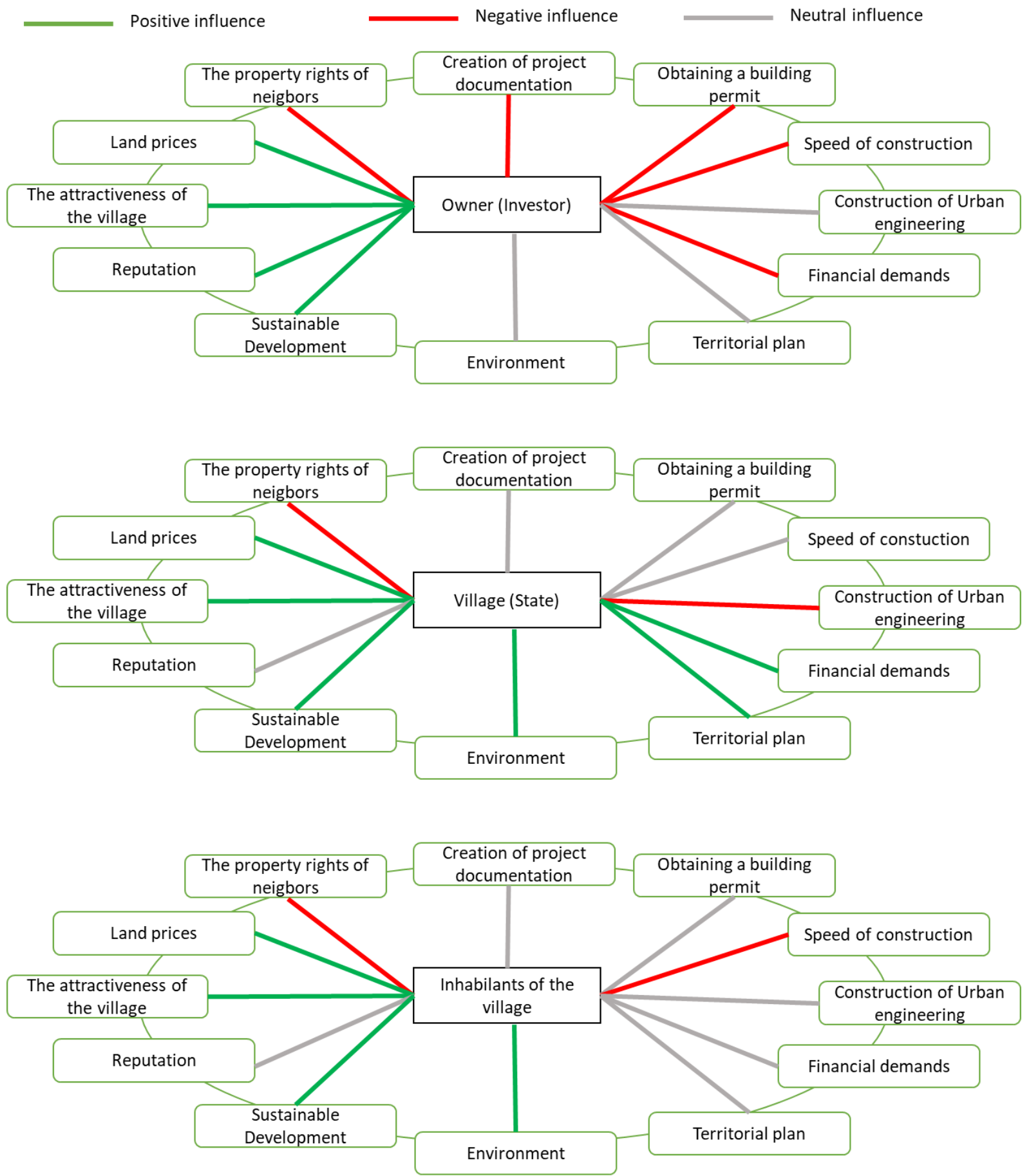

Fig. 7: Schematic representation of positive and negative effects during revitalization of brownfields. (source: author)

The schemes show that revitalization of brownfields is beneficial from the environmental point of view. On the other hand, for the investor it means extension of the construction and not only the process of construction itself but also the time of pre-construction phase extends. Another negative effect is the owners of the surrounding lands do not have to agree with the construction on the brownfield. Regarding economic point of view, it depends very much on the point of view applied. From the investor's point of view construction on brownfield can cause higher expenses but for the municipality (the state budget) it means lowering the costs as in the construction phase but also in the phase of following usage. When construction on a greenfield is taken into consideration is to be 
considered it is more convenient for the investor in terms of the pre-construction phase as well as the construction phase and furthermore for the investor there is the possibility of lowering the economic severity.

Positive influence

Negative influence

Neutral influence
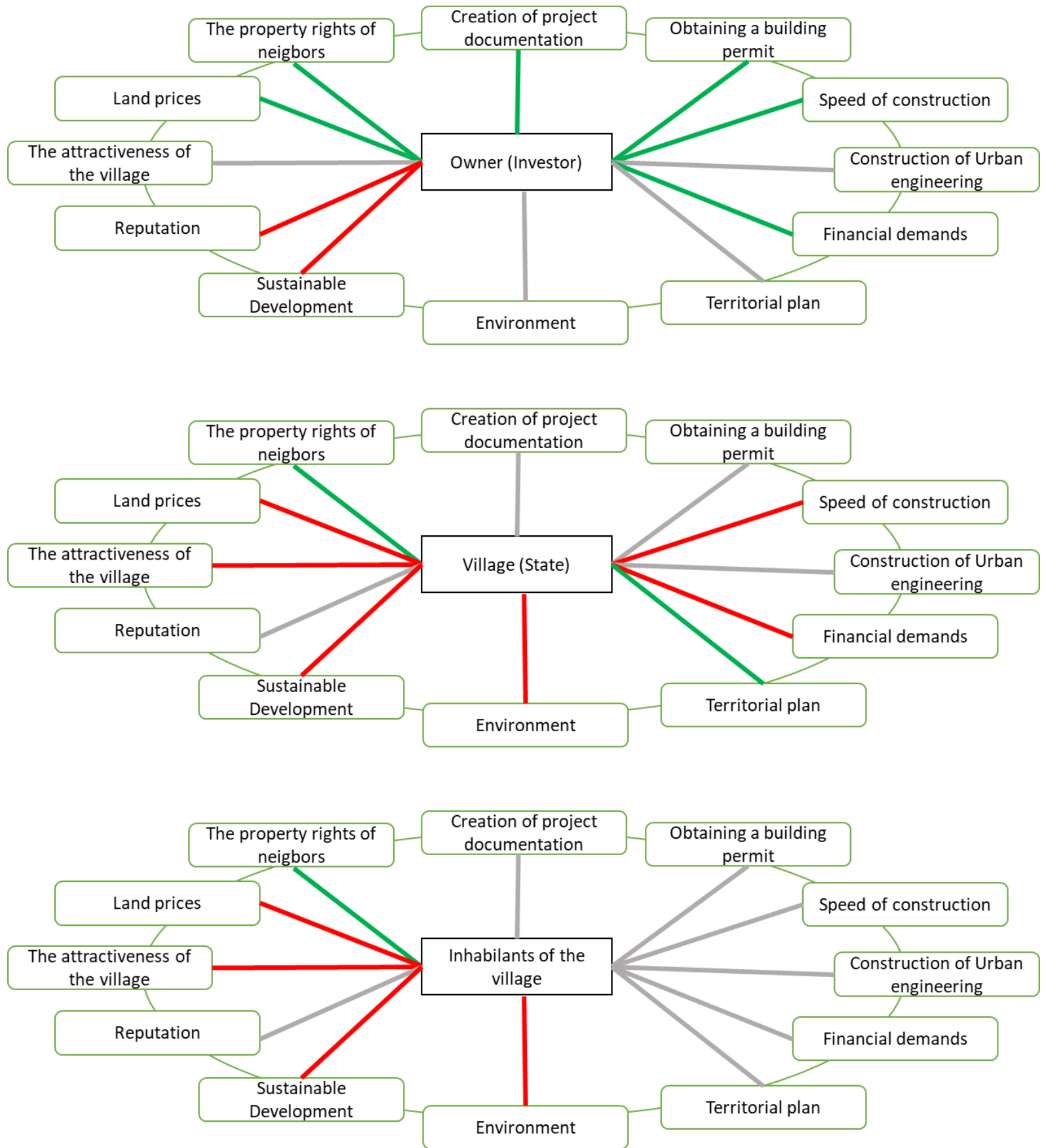

Fig. 8: Schematic representation of positive and negative effects during construction on greenfield. (source: author) 


\section{Conclusion}

In conclusion, it can happen that there is a great number of possibilities of revitalization of objects and areas and that it is almost always very original project and thus no universal methodology can be created. An object remains original and special from the construction until the possible demolition. As it has already been said - the construction industry has begun to grow recently which could become the reason for lowering the number of brownfields. It can be deduced from the cited analysis that the resulting effect of lowering the number of brownfields is overall more positive for all subjects involved.

From one point of view investing into the revitalization is economically less convenient and for the investor more expensive. However, it is not always the case. It is necessary to consider the effectiveness of mere existence of brownfields, not only focus on the costs connected to its revitalization.

Brownfields are most frequently results of decrease of mining, industrial activities, etc. Most people who were previously employed in the industry thus move to different cities to find new job. It is a result of a wrong spatial planning of the municipality at the first place. Furthermore, there has been a growth of brownfields in general due to decreasing of agricultural activities. And there are the reasons why the spatial plans should become the centre of focus if the number of brownfields should be lowered as well as stopping it from growing. This idea should be accepted and taken seriously not only in the Czech Republic. As it has been said before, this problem is spread worldwide.

It is almost impossible to estimate the price of revitalization of some brownfield. Every brownfield has different parameters, age, diversity, and effectiveness. The specific realization of construction cannot be foreseen because there is often no valuable documentation of the object. That is one of the reasons why the BIM method becomes more popular especially for creating models and then for the usage of the building itself.

However, there is one thing that all brownfields have in common. It is the fact that there is always an investor and there is always a solution. It is not always the most economical solution, but it is the way of sustainable development that has to be taken so that the ecological burden is reduced. As the definition of sustainable development states, it is necessary to satisfy the needs of the current generation in such a manner, so the need of the future generations do not have to be reduced.

As it has been stated before, although this issue has been discussed for several years no clear solution has been found and so it would be convenient to create a manual for dealing with brownfields, to create a database of all brownfields and refresh that database, also to create a database of potential brownfields along with proposals of prevention. Another part of the solution would be creating an ideal area of granting for potential investors so that the ineffectiveness of the brownfields is compensated for the investors but at the same time this ineffectiveness would have to be compensated by the state alone.

\section{References}

[1] PFAUNTSCH, R. Der Ingenieur als Stadtplaner: (Inženýr jako urbanista). In: Městský inženýr - městský architekt. Praha: Grand, 2017, ISBN 978-80-87438-88-6.

[2] JACKSON BERGATT, J. et al. Brownfields snadno a rychle: Příručka zejména pro pracovníky a zastupitele obcí. Praha: IURS, 2004, 38 s. at: http://www.brownfields.cz/wpcontent/uploads/2007/11/brownfieldssnadnoalehce.pdf

[3] MAIER, K. Udržitelný rozvoj území. Praha: Grada, 2012. ISBN 978-80-247-4198-7.

[4] Johnston, R., Poulsen, M., Forrest, J. The geography of ethnic residential segregation: A comparative study of five countries (2007) Annals of the Association of American Geographers, 97 (4), pp. 713-738. Cited 121 times. DOI: 10.1111/j.1467-8306.2007.00579.x

[5] BUŇAT, Matěj. Vliv implementace brownfield v městském inženýrství. Praha, 2018. Diplomová práce. ČVUT. 
[6] BUŇAT, Matěj. Objektivizace přístupů k umístění staveb s použitím matematických metod. In: Journal Business \& IT. Praha: CTU in Prague, 2017, s. 20. ISSN 2570-7434.

[7] ALBERINI, A., A. LONGO, S. TONIN, F. TROMBETTA, and M. TURVANI. The role of liability, regulation and economic incentives in brownfield remediation and redevelopment: evidence from surveys of developers. Regional Science and Urban Economics. 2005, 35(4), 327-351. DOI:

10.1016/j.regsciurbeco.2004.05.004. ISSN 01660462. at: http://linkinghub.elsevier.com/retrieve/pii/S0166046204000390

[8] AMEKUDZI, A. a I. FOMUNUNG. Integrating Brownfields Redevelopment with Transportation Planning. Journal of Urban Planning and Development. 2004, 130(4), 204-212. DOI: 10.1061/(ASCE)07339488(2004)130:4(204). ISSN 0733-9488. at: http://ascelibrary.org/doi/10.1061/(ASCE)07339488(2004)130:4(204)

[9] Ministerstvo průmyslu a obchodu : Národní strategie regenerace brownfieldů. Praha, 2008. at: http://www.czechinvest.org/data/files/strategie-regenerace-vlada-1079.pdf

[10] POPESCU, G. a Roberto PATRAŞCOIU. Brownfield sites - between abandonment and redevelopment case study: Craiova city. HUMAN GEOGRAPHIES - Journal of Studies and Research in Human Geography. 2012, 6(1), 91-97. DOI: 10.5719/hgeo.2012.61.91. ISSN 18436587. at: http://humangeographies.org.ro/abstracts/61/6111.html

[11] VRÁBLÍKOVÁ, Jaroslava a Petr VRÁBLÍK. Metodika revitalizace krajiny v Podkrušnohoří. Ústí nad Labem: Univerzita Jana Evangelisty Purkyně, Fakulta životního prostředí, 2010. ISBN 978-80-7414-340-3.

[12] NOVÁČEK, Pavel. Udržitelný rozvoj. 2. vyd. Olomouc: Univerzita Palackého v Olomouci, 2011, 430 s. ISBN 978-802-4427-959.

[13] DANEL, R., and Z. NEUSTUPA. Information support for brownfield revitalization projects. 2016 XIth International Scientific and Technical Conference Computer Sciences and Information Technologies (CSIT). IEEE, 2016, 2016, , 111-115. DOI: 10.1109/STC-CSIT.2016.7589882. ISBN 978-1-5090-2740-8. at: http://ieeexplore.ieee.org/document/7589882/

[14] CUDLÍN, P., F. ZEMEK, J. TĚŠITEL, M. LAPKA a I. HANOUSKOVÁ. Stress concept: Possible tool to study changes in landscape. Ekológia. 2001(20), 3-13.

[15] LYSENKO, V. Analýza využívání vybraných nerostných surovin v České republice z hlediska ochrany životního prostředí. Zpravodaj MŽP. 1996(4), 3-5.

[16] GREENBERG, M., K. LOWRIE, H. MAYER, K. T. MILLER a Laura SOLITARE. The Environmentalist. 21(2), 129143. DOI: 10.1023/A:1010684411938. ISSN 02511088. at: http://link.springer.com/10.1023/A:1010684411938

[17] ŠILHÁNKOVÁ, Vladimíra. Rekonverze vojenských brownfields. Vyd. 1. Pardubice: Univerzita Pardubice, 2006, 218 s. ISBN 80-719-4836-5.

[18] DONG, J. a S. GONG. Restoration and regeneration of industrial brownfield. Boletin Tecnico/Technical Bulletin. 2017. ISSN 0376723X.

[19] VLÁDA ČR. Metodika dodržování principů účelnosti, hospodárnosti a efektivnosti při hospodaření s veřejnými prostředky: Návrh. at: http://www.korupce.cz/assets/protikorupcni-strategie-vlady/na-leta2013-2014/metodika-dodrzovani-principu-3E---navrh.pdf

[20] VITÁSEK, S. a D. MĚŠŤANOVÁ. Life Cycle Cost of a Railroad Switch. Procedia Engineering. 2017, 196, 646652. DOI: 10.1016/j.proeng.2017.08.053. ISSN 18777058. at z: http://linkinghub.elsevier.com/retrieve/pii/S1877705817331806

[21] SCHNEIDEROVA-HERALOVA, R. Life Cycle Cost Optimization Within Decision Making on Alternative Designs of Public Buildings. Procedia Engineering. 2014, 85, 454-463. DOI:

10.1016/j.proeng.2014.10.572. ISSN 18777058. at: http://linkinghub.elsevier.com/retrieve/pii/S1877705814019389

[22] KADEŘÁBKOVÁ, B., MĚŠŤANOVÁ, D. and M. PIECHA. Brownfields: jak vznikají a co s nimi. V Praze: C.H. Beck, 2009. C.H. Beck pro praxi. ISBN 978-80-7400-123-9.

[23] RYDVALOVÁ, P. a M. ŽIŽKA. Economic context of brownfields revitalization: [Ekonomické souvislosti revitalizace brownfields]. Politicka Ekonomie. 2006. ISSN 00323233.

[24] ELLERBUSCH, F. Brownfields: Risk, property, and community value. Local Environment. 2006, 11(5), 559575. DOI: 10.1080/13549830600853486. ISSN 1354-9839. at: http://www.tandfonline.com/doi/abs/10.1080/13549830600853486 